\title{
ВИВЧЕННЯ «СВІТУ ДЗЕРКАЛ» НА ОСНОВІ РЕАЛІЗАЦІЇ МІЖПРЕДМЕТНИХ ЗВ'ЯЗКІВ ТА ПРОФЕСІЙНОЇ ОРІЄНТАЦІЇ СТАРШОКЛАСНИКІВ
}

\author{
Юлія Лимарєва \\ кандидат педагогічних наук, доцент кафедри фізики \\ ДВНЗ «Донбаський державний педагогічний університет» \\ м. Слов'янськ, Україна \\ ORCID ID 0000-0002-5828-0231 \\ ulialymareva23@gmail.com \\ Лариса Белошапка \\ учитель фізики першої категорії, \\ старший учитель \\ Слов’янська загальноосвітня школа I-III ст. № 18 \\ м. Слов'янськ, Україна \\ ORCID ID 0000-0003-3534-9088 \\ larisabeloshapka@gmail.com

\section{Олександр Бслошапка} \\ старший викладач кафедри фізики \\ ДВНЗ «Донбаський державний педагогічний університет» \\ м. Слов'янськ, Україна \\ ORCID ID 0000-0001-7448-3832 \\ beregslav2015@gmail.com
}

\begin{abstract}
Анотація. У статті розглянуто проблему формування комплексних знань старшокласників на основі міжпредметних зав'язків та професійної орієнтації. На прикладі нестандартного уроку-конференції «Світ дзеркал» висвітлено практичні можливості організації навчання фізиці з урахуванням спектру інтересів звичайного різнорівневого учнівського колективу. Врахування інтересів та здібностей учнів, а також їх залучення до посильної активної участі у підготовці та проведенні навчального заняття забезпечує усвідомлення й глибше розуміння важливості розглядуваної на уроці проблеми та необхідність використання суміжних знань для подальшого ii дослідження або загальної обізнаності особистості. Посильність практичних завдань та їх невідривний зв'язок із життям та побутом $\epsilon$ переконливим доказом доцільності вивчення фізики як загальноосвітньої навчальної дисципліни у закладах загальної середньої освіти.

Ключові слова: міжпредметні зв'язки; практичність; дзеркало; симетрія; технологічний процес; логічний зв'язок; навчання; самоосвіта; професійна орієнтація.
\end{abstract}

Постановка проблеми в загальному вигляді. Проблема полягає у виваженому поєднанні та використанні знань з різних навчальних предметів на 
уроках фізики з метою формування комплексних свідомих знань учнів в умовах різнорівневого учнівського колективу. Уроки фізики, засновані на реалізації міжпредметних зв'язків, дають можливість учням з різним рівнем навчальних здібностей з предмету повноцінно реалізувати себе. Таке переконання засноване на тому, що кожний учень може приймати активну та посильну участь виходячи із власних навчальних уподобань та незалежно від «складної наукової фізики». У такий спосіб індивідуальність кожного учня врахована на уроці фізики, причому незалежно від його рівня навчальних досягнень 3 цієї дисципліни. Зважаючи, що знання про світло даються до опанування достатньо складно, доречним буде урізноманітнити вивчення саме цієї теми.

Аналіз останніх досліджень і публікацій. Зазначена проблема не є новою. Окремі iї аспекти розкрили своїх у роботах сучасні науковці Т. Вокер, Н. Волкова, І. Гавриш, Р. Гуревич, О. Дубасенюк, О. Остапчук, М. Сметанський та інші. Активність учня завжди вимагає активності учителя, а це означає, що вчитель завжди має бути готовим до самоосвіти у напрямку інтересів учня. Вміння вичерпно та різнобічно розкривати тему, вільно в ній орієнтуватися виступає запорукою вмілої організації свідомого підходу учнів до навчання (Гавриш, 2006). Готовність вчителя до освітніх інновацій та інтеграція методів, мобільність підходів та педагогічних поглядів заснованих на проектуванні загальної освіти на подальше професійне навчання ввірених йому старшокласників стає ознакою можливості продуктивної співпраці на перспективу (Остапчук, 2004).

Навчальна діяльність у розмові, дискусії та рівному діалозі учасників; навчання у співпраці; бажання та інтереси учня - це закони, за яким має бути організована сучасна освіта. Вчитель виступає порадником, рівноправним співдіячем та помічником у розумінні істини. За таким умов помічник має бути широко обізнаний у темі розмови (Вокер, 2018). Діяльнісний підхід при цьому виступає як основа виникнення запитань, учнівська допитливість - природня потреба людини в основі якої $\epsilon$ мотив задоволення власних потреб (Сметанський, 2000). Організація діалогового навчання у контексті професійнопедагогічної спрямованості та створення конструктивного діалогу на основі знань суміжних дисциплін часто виступають потужним мотиватором подальшої самоосвітньої професійної діяльності та запорукою успішного становлення особистості як фахівця у певній галузі (Волкова, 2006; Старощук, 2004).

Формулювання цілей статті. На основі зазначеного вище за мету статті поставлено: висвітлити практичні можливості поєднання знань різних навчальних предметів та сфер діяльності людини на уроці-конференції з фізики. 


\section{Ю. ЛИМАРЄВА, Л. БЄЛОШАПКА, О. БЄЛОШАПКА \\ Вивчення «Світу дзеркал» на основі реалізації міжпредметних зв'язків та професійної орієнтації старшокласників}

Результати дослідження. Враховуючи програмні вимоги перед уроком «Світ дзеркал» ставляться такі задачі: з'ясувати особливості відбивання світлових променів від дзеркальних поверхонь, дифузних відбивань, формувати знання учнів про зміну ходу променів у однорідному середовищі, встановлення необхідних для цього умов, сформувати уявлення про роль металів в процесі виробництва дзеркал, їх фізико-хімічні властивості та сфери застосування; акцентувати увагу учнів на можливостях інтеграції знань з курсів хімії, фізики, історії, літератури, математики; поглиблювати навички роботи з додатковою літературою, розвивати вміння виділяти головне, суттєве, порівнювати, узагальнювати; сприяти розвитку емоційних якостей особистості, формуванню комунікативних вмінь; формувати науковий світогляд, цілісну картину світу. забезпечити формування в учнів уміння застосовувати на практиці закони відбивання світла.

Цікавим буде якщо починати урок, так би мовити «з віддаля», а саме із незвичайного запитання, яким починається одна із загадок про дзеркало та яке стовідсотково приверне увагу: «Хто завжди правду каже? ... » Але отримати правильну відповідь відразу малоймовірно, тоді загадка продовжується:

Який $\epsilon$, таким покаже,

I без слів про все розкаже.

На нього дивишся, а себе бачиш.

А після отримання правильної відповіді, що тепер не змусить довго себе чекати, бо є очевидною, доцільно надати слово літературним знавцям, які введуть до таємничого дзеркального світу.

Дивлюся в дзеркало і бачу там себе.

Воно не збреше, усю правду скаже.

Про серця біль, що довго не мине

Та бороздою зморшок різко ляже.

І очі... Очі - чисті і сумні.

В них не сховати розпач й порожнечу.

І хоч вуста й всміхаються мені.

Та по щоці сльоза - душа це плаче.

Та випадає дзеркало і вмить

Геть розлітається на дріб'язкові скельця.

Розбилося все вщент - і не злічить, і склеїти

Їх більше вже не вдасться.

У такий спосіб учитель запрошує у «Світ дзеркал», далі підтримуючи увагу дивними запитаннями: Кого ви бачите у дзеркалі? ... Чи себе ви бачите у 
дзеркалі? ... Як побачити у дзеркалі себе? ... т. ін., кожне наступне з яких змушує замислитися над правильністю відповіді на попереднє. Намагаючись відповісти на них на основі власного досвіду є можливість привернути або підтримати увагу навіть тих учнів, зацікавленість яких фізикою ніколи виявлялася.

Сьогодні важко уявити собі життя без дзеркала. Незначна дрібничка, але який душевний дискомфорт! Здається, що очевидне і відоме, але... за мить постають запитання на які нажаль відсутне чітке свідоме розуміння відповіді. Наприклад: Що ж являє собою дзеркало? У чому його таємничість? Коли та де з'явилося? Якими способами виготовляють та де використовують? Та ще на багато інших запитань хочеться отримати відповідь. Між тим, уже від початку 3'являється відчуття, що потрапиш у дивовижний, таємничий та казковий світ. Такий вступ змінює сприйняття уроку як етапу навчання, перетворюючи його у пізнавальний захід.

Далі у колективній бесіді з’ясовуються основні характерні риси, які має те, що називають «дзеркало» $\mathrm{i}$, у такий спосіб, поступово приходять до одного із визначень: «Дзеркало - це відшліфована поверхня, що відображає предмети, які перед нею знаходяться, а також спеціально виготовлений предмет 3 такою поверхнею».

Подальша справа може бути за учнями, які цікавляться історією та які за заздалегідь підготованим матеріалом презентують інформацію про перші дзеркала та винахідників, що беззаперечно від самого початку знову приверне увагу слухачів, бо: як не парадоксально, але першим дзеркалом в історії людства було звичайне відображення у воді, а його винахідником була природа, що в подальшому надала можливості вдосконалення та використання людині.

Вік найстаріших на Землі дзеркал становить близько 7 тис. років. Археологи вважають, що найдавніші люстерка знайдені в Туреччині - це поліровані шматки обсидіану (магматична порода, різновид вулканічного скла, що утворюється в результаті швидкого охолодження лави), яким понад 7500 років. Проте ні в одне з античних дзеркал не можна було розглядати себе.

Епоха настінних дзеркал почалася в Китаї, коли в якості них спробували використовувати бронзові диски. В XIII столітті (1240р.) вже можна було придбати дзеркало у склодува, щоправда зображення було дещо спотвореним через нерівну поверхню.

Через 250 років у Франції винайшли інший вид дзеркала, технологія виготовлення якого полягала у наступному: на одну з поверхонь плоского скла наклеювали тонку фольгу з олова. Дана технологія одержала поширення лише згодом у Венеції. Від цього і пішла назва - венеціанські дзеркала, що були 
недосяжною розкішшю для простого народу. Дзеркало здавалося дивом, коли воно цінувалося на вагу золота Вартість одного венеціанського дзеркала дорівнювала вартості невеликого морського судна. У 1500 році у Франції звичайне плоске дзеркало розміром $120 \times 80$ см коштувало в 2,5 рази дорожче, ніж картина Рафаеля.

Дуже швидко дзеркало стало важливим елементом меблювання й декору та зажадало відповідного обрамлення, де на повну була нагода показати майстерність та винахідливість ремісникам, художникам, ювелірам та мистецтвознавцям. Дзеркалами прикрашали помешкання. Багатії створювали навіть дзеркальні кімнати, а у старовинних замках завдяки використанню системи дзеркал передавали зображення людей з однієї кімнати в іншу.

Знатні дами дзеркальця вставляли в кільця і сережки замість дорогоцінних каменів та замовляли собі сукні, обшиті дзеркальними шматочками.

Для розширення загальних історичних знань про дзеркало та додаткового зацікавлення доцільною буде інформація про дзеркальний кабінет французької королеви Марії Медичі зі 119 венеціанських дзеркал та особистий дзеркальний подарунок їй від майстрів - унікальне дзеркало, оздоблене агатами, оніксами, смарагдами й інкрустоване дорогоцінними камінням, яке сьогодні зберігається в Луврі.

Будучи переконаними у магічній силі дзеркала у давнину люди надавали йому особливої уваги: вважали, що воно здатне відвернути недобрі погляди та наміри, біду та негоду. Здається, щось пов'язане із здатністю дзеркала змінювати напрямок енергії на підсвідомому рівні виявлялося у же у давнину, бо насправді ж така поверхня відбиває промені.

Не залишилося дзеркало і поза увагою народної мудрості, яка згадує його у таких висловах як:

- Дружба - мов дзеркало: розіб'єш - не склеїш.

- Друзі - дзеркало одне для одного.

- Нащо сові дзеркало, коли вона й так знає, що гарна.

- Нічого дзеркало винить, коли пика погана.

- Виміняв сліпий у глухого дзеркало на цимбали!

На основі історичних відомостей учитель має зробити підсумок та пов'язати історію із сучасністю. I далі доцільно надати слово хімікам та технологам, які ознайомлять із особливостями виготовлення різних типів дзеркал.

До винаходу дзеркального скла в справу йшли камінь і метал та гірський кришталь. Сьогодні дзеркала можуть бути металевими, 3 ретельно 
відполірованою поверхнею, та скляні, з нанесеними на їх поверхню металами: золото, срібло, бронза, олово, мідь. Побутові дзеркала виготовляють з срібною або алюмінієвою основою. Міцніші моделі виготовляють із застосуванням срібла. Вони довго зберігають свою якість навіть при високій вологості повітря, тому їх можна вішати де завгодно.

Технологічний процес створення дзеркала не $є$ складним та багатоетапним. Між тим він $є$ цікавим та доречним для загального огляду на уроці. Тому довірити повідомлення на таку тему можна тим учням, які цікавляться виробництвом. Орієнтиром для їхніх повідомлень мають бути наступні етапи:

- необхідність основи для дзеркала - рівного скляного листа;

- склад та виготовлення шихти;

- скломаса та іiї температурна обробка;

- охолодження та нарізка скляної основи;

- методи перевірки поверхні на наявність дефектів;

- нанесення металу;

- деякі особливості «технологічної» класифікації дзеркал.

Щодо останнього пункту, слід брати до уваги, що сучасні дзеркала стають в нагоді багатьом фахівцям: лікарям, перукарям, модельєрам, дослідникам у різних галузях. Тому їх виготовляють: для меблів; в якості оздоблювальних матеріалів (різновиди дзеркальної плитки); в авто-виробництві; для косметичної індустрії; для медицини та інших наукових галузей; у виробництві одягу і взуття; для виготовлення всіляких іграшок та декору.

Для нас дзеркало - звичайний атрибут сучасного інтер'єру. Тому, беручи це до уваги на уроці настав час дати слово фізикам та познайомитися докладніше із особливостями дзеркала, а саме: отримати відповіді на запитання Які бувають дзеркала? та Які властивості вони мають? Іншими словами, наступні доповідачі мають дати вичерпні пояснення про те, що зображення 3'являється завдяки відбиванню світлових променів та законам які при цьому працюють, що були нещодавно вивчені. Виступи учасників мають при цьому розкрити такі опорні відомості як:

- дзеркальне та дифузне відбивання,

- створення зображення у плоскому дзеркалі,

- правила побудови зображень у плоскому дзеркалі,

- криві дзеркала та зображення у них,

- «Кімната сміху»,

- правила побудови зображення у сферичних дзеркалах,

- сфери застосування різних типів дзеркал. 
Така інформація має бути представлена наочно на слайдах або демонстраціях.
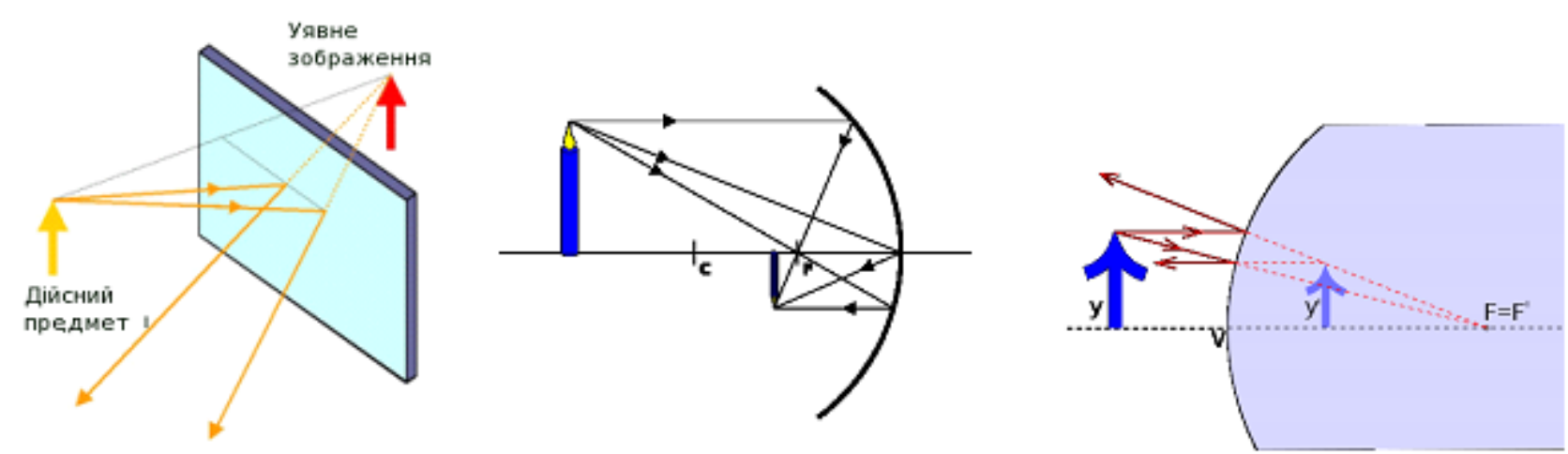

Рис. 1. Хід променів у дзеркалах різних видів

Демонстрація дзеркал - плоского, увігнутого, випуклого наочно переконує у наявності спільних та відмінних їх властивостей.

Доцільним буде провести аналогію кривого дзеркала із «збудженою» поверхнею води (найпершого дзеркала).

Так, поряд $з$ плоскими дзеркалами, якими ми зазвичай користуємося, існують увігнуті і опуклі. Для порівняння доцільно розглянути хід променів у різних типах дзеркал, наприклад на основі нижче поданих малюнків.

Але криві дзеркала використовують не лише для веселощів. Наприклад, вони допомагають водіям на дорозі, розширюючи поле видності та запобігаючи, таким чином, створенню аварійних ситуацій на дорогах.

У дзеркалі всі предмети «перевертаються». Предмет і його зображення в плоскому дзеркалі є симетричними фігурами. Але чому праве стає лівим? Саме у цьому полягає краса симетрії й до справи доречно взятися математика, які нададуть інформацію про види симетрії та правила ії отримання. Варто, до того ж, акцентувати увагу на осьовій симетрії: саме вона сприятиме усвідомленню знань про зворотність дзеркального зображення).

Доповідь математиків однозначно має бути підтримана наочністю та прикладами із різних сфер життя та діяльності людини. Для прикладу зміст наочності з цього питання подано на рисунку нижче.

На основі почутого від фізиків та математиків знавці літератури можуть розповісти про помилки які робили літературні герої не знаючи законів фізики. Наприклад, маленька Керола із країни Задзеркалля довго не змогла подолати бажану дорогу бо кожного разу поверталася додому. Та лише зрозумівши, що у Задзеркаллі закони руху так само обернені, як і нерухомі відображення, вона змогла дістатися цілі.

Професіоналізм педагога: теоретичні й методичні аспекти. - Вип. 14 (Ч. 2). - Слов’янськ, 2021. 
Ю. ЛИМАРЄВА, Л. БЄЛОШАПКА, О. БЄЛОШАПКА

Вивчення «Світу дзеркал» на основі реалізації міжпредметних зв'язків та професійної орієнтації старшокласників
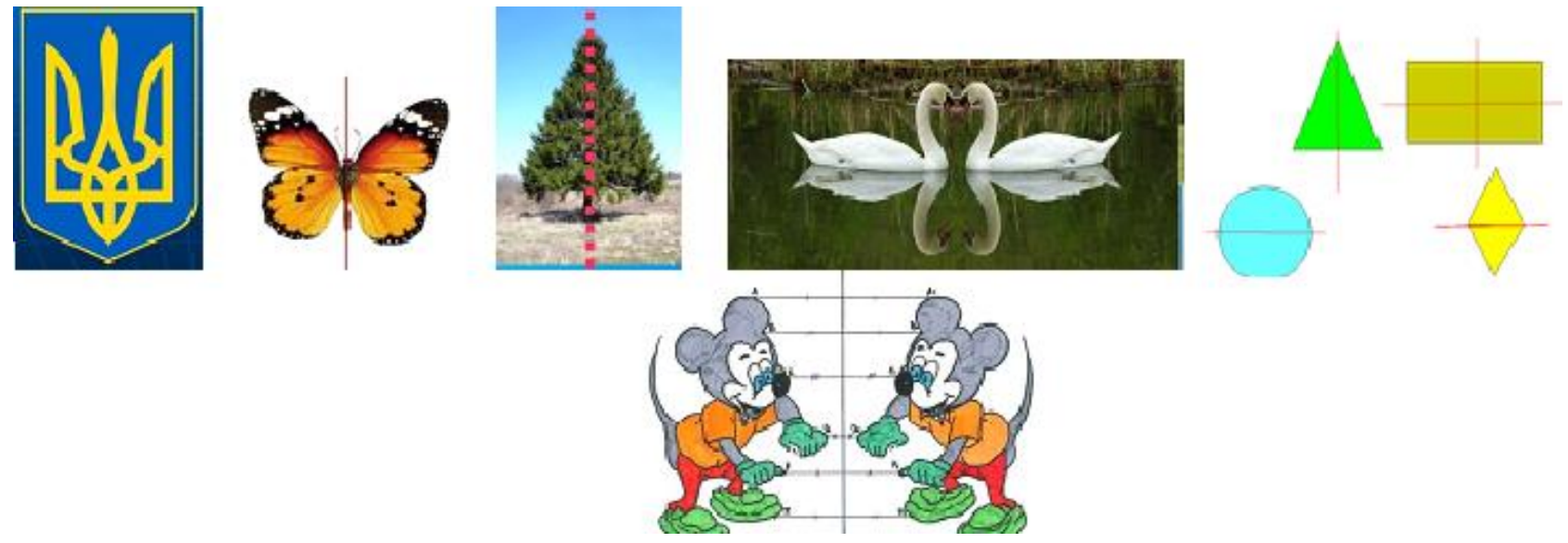

Рис. 2. Приклади симетрії та ї̈ побудова

3 метою формування вмінь застосування отриманих знань та урізноманітнення видів діяльності доцільним буде запропонувати учасникам кілька практичних завдань. Наприклад:

1. Хто скоріше знайде усі літери друкованої абетки, що:

А) не спотворюються лише у вертикальному дзеркалі: (А, Л, П, Т, Ш, М, Ï);

Б) не спотворюються лише у горизонтальному дзеркалі: (В, С, Ю);

В) не спотворюються у вертикальному та горизонтальному дзеркалі: (O, $\Phi$, $\mathrm{H}, \mathrm{X}, \mathrm{I})$;

Г) мають лише вертикальну осьову симетрію: (А, Л, Т, П, Ш, М, Ї);

Д) мають лише горизонтальну осьову симетрію: (B, С, Ю);

Е) мають обидві осьові симетрії: $(\mathrm{O}, \Phi, \mathrm{H}, \mathrm{X}, \mathrm{I})$;

2. Завдання «пастка»: Що можна сказати про наведені фото?

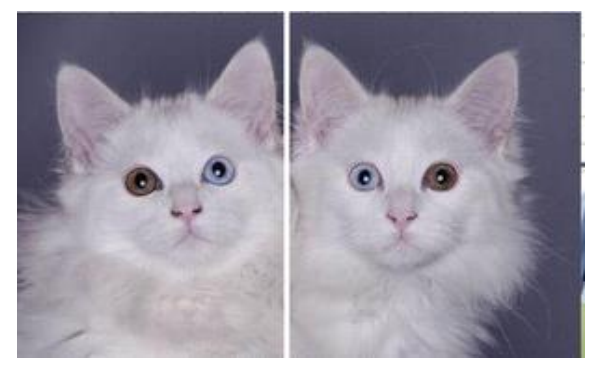

Рис. 3. Завдання-«пастки»

При цьому, залежно від загального рівня учнівського колективу можна надати додаткові пояснювальні запитання типу: На малюнку .... фото двох різних котів? ... кіт та його зображення у плоскому дзеркалі? ... два різних фото одного й того ж самого кота? ... інша думка. При цьому позиція учнів щодо правильної відповіді має бути обов'язково аргументована. 
3. Як зі звичайного аркушу паперу «зробити» дзеркало? ... або Що треба зробити, щоб у ньому побачити зображення предмету?

4. Звичайна ложка на кухні $\epsilon$ також представником «родини кривих дзеркал». При цьому доцільно обмежити вхідну інформацію та запропонувати в якості домашнього завдання визначити особливості власного відображення в опуклому та увігнутому дзеркалі з використанням ложки. Виявити особливості власного зображення у столовій ложці: за різних положень ложки (увігнутою поверхнею, опуклою поверхнею, вертикальне або горизонтальне розташування) зробіть висновки про напрямок викривлення та залежність від радіуса кривизни дзеркальної поверхні.

Всі запропоновані завдання можуть вирішуватися як на уроці, так і під час позаурочної діяльності. Цей вибір має бути обраний самостійно учителем та запропонований учням залежно від рівня їхньої загальної підготовленості та активності на уроці.

Наступна частина заняття, враховуючи час, є зазвичай менш продуктивною, то для підтримки уваги та активності доцільно запропонувати щось цікаве. Тому, настав час для фокусників. Продемонструвати кілька цікавих дослідів типу: «Третя рука» або «Невагомість» буде цілком доречним. Вони надзвичайно простими, але всеж таки привертають увагу.
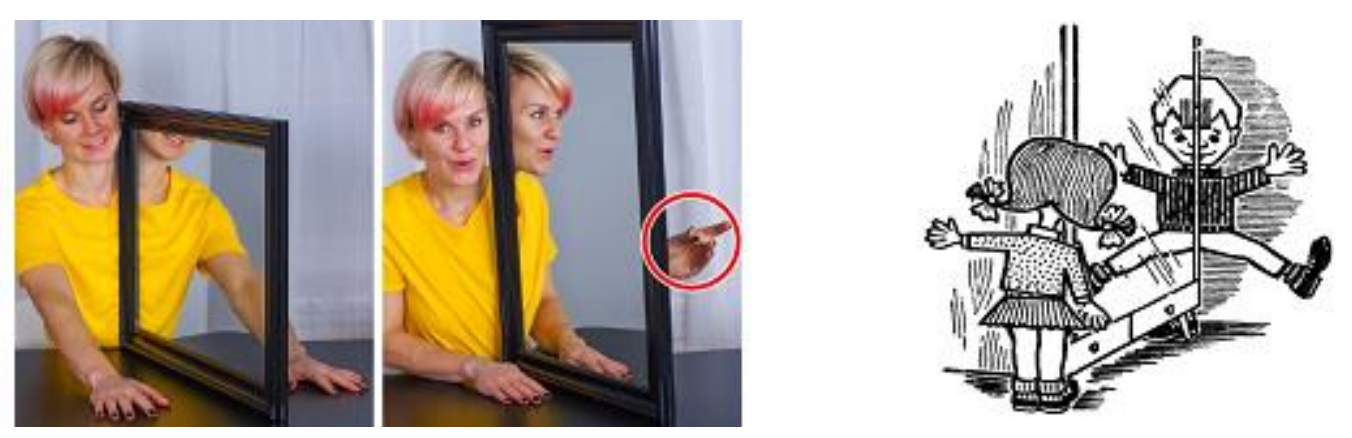

Рис. 4. Приклади фокусів із дзеркалом

Враховуючи знання 3 фізики тепер їх можна дуже швидко обеззброїти фокусників, але й з легкістю відтворити в домашніх умовах, ставши самому фокусником.

Наступним етапом доцільно провести огляд сучасних напрямків дослідження та вдосконалення дзеркал.

Тут має місце, наприклад, трикутний акваріум-дзеркало, винайдений у 2004 році у Японії. Така конструкція дає пряме відображення об'єкту. При його розгляді доцільний наочний супровід моделі та спостереження побудови ходу

Професіоналізм педагога: теоретичні й методичні аспекти. - Вип. 14 (Ч. 2). - Слов’янськ, 2021. 
променів у ньому. Такий підхід наочно переконає учасників у дійсності припущень винахідників та можливості практичної реалізації ідеї.

Не менш цікавими є спроби винайдення дзеркала майбутнього, яке намагаються впровадити спеціалісти Національного політехнічного інституту Мексики працюють над створенням електронної системи, що здатна прогнозувати еволюцію обличчя людини. Можливість створення перспективного фото буде вагомою практичною знахідкою для суспільства. Сьогодні запропоновано кілька електронних програм, що намагаються моделювати вікові зміни зовнішності. Вони є цікавими для використання та вдосконалення.

Швидко та непомітно у бесіді та співпраці прийшов час підводити підсумки. Нас оточує світ дзеркал. Ми звикли до них. Ми спокійно дивимося в дзеркало вранці, поправляємо зачіску або посміхаємося своєму відображенню. I зовсім не замислюємося, що дзеркало - не на стільки просте, яким здається на перший погляд.

Ми пізнаємо себе, ми ідентифікуємо себе, порівнюємо з іншими людьми, а це ж можна зробити тільки за допомогою дзеркала.

Не зайвим буде запросити до участі тих, хто цікавиться тваринним світом та отримати відповідь на запитання: «Як домашні улюбленці реагують на дзеркало?» почувши цікаві доповіді на тему: «Дзеркальний» світ тварин».

Також доречною буде система маленьких презентацій або мініповідомлень на тему застосування дзеркал у різних сферах діяльності людини рослинництві, садівництві, медицині і ін. (у формуванні даного переліку слід брати до уваги сферу зацікавленості учнів конкретного колективу).

Не зайвим буде сказати кілька слів про догляд за дзеркалом та роздати слухачам відповідні пам'ятки.

Підсумок уроку вимагає відповідей на такі запитання до учнів:

- Де вам знадобляться отримані знання?

- Що особисто було для вас корисним та цікавим?

- Про що б ви ще хотіли дізнатися додатково? і т. ін.

На кінець, коли всі відповіді отримані, можна запропонувати таку собі «виховну хвилинку»: із дзеркалом пов'язані безліч прикмет і повір'їв, в які люди вірять. Один із головних законів життя - це закон дзеркала. Світ лише повертає нам наше, а тому стане в нагоді така притча, в якій багато мудрості і правил поведінки для кожного на щодень, навіть скоріше на щомить...

«В палаці одного вельможі була незвичайна зала: стіни, стеля і підлога в ній були дзеркальні. Якось абсолютно випадково в цю залу забіг собака. Він 
розгубився, побачивши довкола себе зграю подібних собі створінь і вишкірив зуби. Пси відповіли йому тим же... Тоді собака відповів їм гучним гавканням, $\mathrm{i}$ пси всі також разом подали голос... Собака почав метушитися, бігати туди-сюди і гавкати, проте 3 усіх сторін на нього кидалися йому подібні створіння 3 вишкіреними пащами і неймовірним гавкотом. Цілу ніч провів біднесенький в оточенні озвірілої зграї. А вранці слуги вельможі знайшли в залі його бездиханне тіло. В нього розірвалося серце. Проте, все могло скластися інакше, якби собака, увійшовши до зали, крутнув хвостом, і протягнув тим, хто дивився на нього із дзеркала, лапу: на знак дружби».

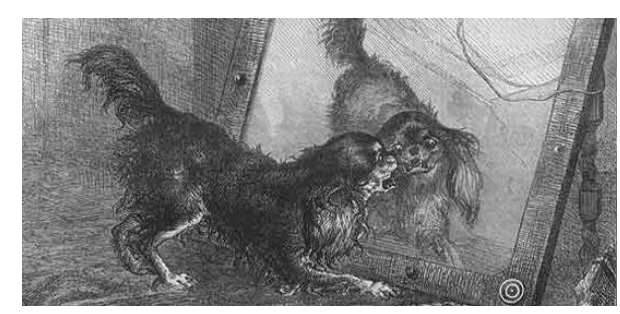

Рис. 5. Притча

Навколишній світ - це дзеркало, яке повертає людині його ж зображення. Насупишся, i дзеркало відповість тобі хмурістю. Посміхнися, i воно посміхнеться тобі у відповідь. Урок скінчився - враження та знання залишилися.

Висновки $з$ дослідження і перспективи подальших розвідок у цьому напрямі. Насиченість уроку-конференції матеріалом та характерна його різноманітність дозволяє забезпечити більш високий коефіцієнт корисної дії уроку для учнів з різним рівнем навчальних досягнень з фізики. Прив'язуючи інтереси учня до уроку фізики учитель одночасно прив'язує фізику до інтересів учня, таким чином з'являються додаткові з'єднувальні ланцюжки, що забезпечують певний рівень загальної підготовки старшокласника до подальшого навчання і отримання спеціальної освіти.

Подані можливості поєднання розрізненої інформації та фактів про дзеркала із різних галузей знань забезпечують усвідомлене сприйняття матеріалу. При цьому важливим $є$ те, що кожний із учасників такого уроку засвоїть вибіркову та корисну особисто для нього інформацію.

Зазначений підхід до організації та проведення уроку надає можливості повністю виконати вимоги передбачені навчальною програмою з фізики, а пора на міжпредметність та професійну орієнтацію старшокласників забезпечує можливість формування комплексних практичних знань. Тому перспективу подальших досліджень бачимо у створенні та впровадженні у навчальний процес

Професіоналізм педагога: теоретичні й методичні аспекти. - Вип. 14 (Ч. 2). - Слов’янськ, 2021. 
закладів загальної середньої освіти серії уроків за розділами фізики заснованих на використанні та інтеграції знань із різних навчальних дисциплін та орієнтованих на врахування подальшої професійної орієнтації старшокласників.

\title{
СПИСОК ВИКОРИСТАНИХ ДЖЕРЕЛ
}

1. Вокер, Т. (2018). Як навчають у Фінляндї. Найкраша шкільна освіта. Н. Лавської (Перекл.). Київ, Україна: Видавнича група КМ-Б.

2. Волкова, Н.П. (2006). Професійно-педагогічна комунікація. Київ, Україна: Видавництво: ВЦ «Академія».

3. Гавриш, І.В. (2006). Теоретико-методологічні основи формування готовності майбутніх учителів до інноваційної професійної діяльності. (Автореф. дис. д-ра пед. наук). Луганськ, Україна.

4. Гуревич, Р.С. (2014). Компетентнісний підхід у професійно-педагогічній освіті. Компетентнісний підхід в освіті: теоретичні засади і практика реалізації: Методол. семінар Нац. акад. пед. наук України. (Ч.2, с.137-143). Київ, Україна: Ін-т обдарованої дитини НАПН України.

5. Демидюк, О.В. (2007). Нетрадиџійні уроки фізики в школі: Навчальний посібник для фізичних спеціальностей. - Житомир, Україна: Вид-во ЖДУ ім. І. Франка.

6. Дубасенюк, О.А. (2010). Компетентнісний підхід у професійній підготовці вчителя. Формування естетичної компетентності особистості засобами народознавства. 10-16. Житомир, Україна: Вид-во ЖДУ ім. І. Франка.

7. Ненашев, І.Ю. (2005). Нестандартні уроки. Харків, Україна: Вид. група «Основа».

8. Остапчук, О.С. (2004). Діяльність учителя: готовність до інновацій. Кривий Ріг, Україна: ПП «Іріда».

9. Сметанський, М.I. (2000). Методологічні засади активізації навчально-пізнавальної діяльності студентів. Шлях освіти, 4, 9-13.

10. Старощук, В.А. (2004). Дванадиять кроків до майстерності. Харків, Україна: Вид. група «Основа».

\section{STUDYING THE "WORLD OF MIRRORS" ON THE BASIS OF IMPLEMENTATION OF INTERDISCIPLINARY RELATIONS AND PROFESSIONAL ORIENTATION OF SENIOR STUDENTS}

\author{
Yuliia Lymarieva
}

Candidate of Pedagogical Sciences, Associate Professor of the Department of Physics

SHEI "Donbas State Pedagogical University"

Sloviansk, Donetsk region, Ukraine

ORCID ID 0000-0002-5828-0231

ulialymareva23@gmail.com

\section{Larysa Bieloshapka}

teacher of Physics of the first category, senior teacher

Sloviansk secondary school № 18

Sloviansk, Donetsk region, Ukraine

ORCID ID 0000-0003-3534-9088

larisabeloshapka@gmail.com 


\title{
Oleksandr Bieloshapka
}

\author{
Senior Lecturer of the Department of Physics \\ SHEE "Donbas State Pedagogical University" \\ Sloviansk, Donetsk region, Ukraine \\ ORCID ID 0000-0001-7448-3832 \\ beregslav2015@gmail.com
}

\begin{abstract}
The article is devoted to the consideration of the problem of forming complex knowledge of high school students on the basis of intersubject connections and professional orientation. The problem posed is not new. Certain aspects are disclosed in the works of domestic and foreign teachers. However, it is actively transforming over time, and, therefore, requires a mobile approach to its consideration in time. This is due to many factors.

The student's activity always requires the teacher's activity, which means the second must be ready for self-education in the direction of the interests of the first. The ability to fully and versatile disclose a topic, to navigate freely in it is the key to the successful organization of a conscious approach of students to education.

The teacher's readiness for educational innovations, the ability to integrate pedagogical methods, the mobility of his approaches and views, based on the design of general education for further vocational training, is considered by modern pedagogy as an opportunity for productive cooperation in the future.

Educational activity based on conversation, dialogue, discussion, as well as joint activities of all participants in the educational process is a powerful motivator for the conscious formation of skills in organizing further professional self-education.

On the example of a non-standard lesson-conference "World of Mirrors", the practical possibilities of organizing teaching physics are revealed, taking into account the entire spectrum of interests of an ordinary student collective of different levels. Taking into account the interests and abilities of students, as well as their involvement in their feasible active participation in the preparation and conduct of a lesson provides awareness and a deeper understanding of the importance of the problem considered in the lesson, the need to use knowledge of related academic subjects for its further research or general awareness. The feasibility of practical tasks and their close connection with life and everyday life is a clear proof of the advisability of studying physics as a general educational discipline in an educational institution.

The saturation of the lesson-conference with material and its characteristic variety allows for a higher efficiency of the lesson for students with different levels of educational achievements in physics. By tying the interests of the student to the physics lesson, the teacher simultaneously ties physics to the interests of the student, thus additional connecting chains appear that provide a certain level of general preparation of the senior pupil for further education and obtaining special education.

The approach to organizing and conducting lessons presented in the article makes it possible to fully fulfill the requirements provided for by the curriculum in physics. The reliance on interdisciplinary and professional orientation of students provides the formation of complex practical knowledge.
\end{abstract}

Key words: interdisciplinary links; practicality; mirror; symmetry; technological process; logical connection; education; self-education; professional education.

\section{REFERENCES}

1. Andreev, V.I. (2000). Pedagogy: a training course for creative self-development. Kazan, Russia: Tsentr innovatsionnykh tekhnologiy.

Професіоналізм педагога: теоретичні й методичні аспекти. - Вип. 14 (Ч. 2). - Слов’янськ, 2021. 


\section{Ю. ЛИМАРЄВА, Л. БЄЛОШАПКА, О. БЄЛОШАПКА}

Вивчення «Світу дзеркал» на основі реалізації міжпредметних зв'язків та професійної орієнтації старшокласників

2. Walker, T. (2018). How to teach in Finland. Best School Education. N. Lavska (Tr.). Kyiv, Ukraine: Vydavnycha hrupa KM-B.

3. Volkova, N.P. (2006). Professional and pedagogical communication. Kyiv, Ukraine: "Akademiya".

4. Havryysh, I. V. (2006). Theoretical and methodological foundations of forming readiness of uture teachers for innovative professional activities. (Extended abstract of Doctoral dissertation). Luhansk, Ukraine.

5. Hurevych, R.S. (2014). Competency-based approach in vocational and pedagogical education. Kompetentnisnyi pidkhid v osviti: teoretychni zasady i praktyka realizatsiyi: Metodol. seminar Nats. akad. ped. nauk Ukrayiny. (Part 2, pp. 137-143). Kyiv, Ukraine: In-t obdarovanoyi dytyny NAPN Ukrayiny.

6. Dubaseniuk, O.A. (2010). Competency-based approach in teacher training. Formuvannya estetychnoyi kompetentnosti osobystosti zasobamy narodoznavstva. (10-16). Zhytomyr, Ukraine: Vyd-vo ZHDU im. Franka

7. Smetanskyii, M.I. (2000). Methodological bases of activization of students learning and cognitive activity. Shliakh osvity, 4, 9-13.

Матеріали надійшли до редакції 19.04.2021 р. 